Лігус Ольга Марківна,
кандидат мистецтвознавства,

Київський національний університет культури і.мистецтв

\title{
СТИЛЬОВИЙ ПОСТУП РОМАНТИЗМУ В УКРАЇНСЬКІЙ ФОРТЕПІАННІЙ МУЗИЦІ ХІХ - ПОЧАТКУ ХХ СТ. (на прикладі еволюції жанру пісні без слів)
}

У статті досліджується проблема стильового поступу романтизму в украӥнській фортепіанній музиці XIX-nоч. XX стст. на прикладі еволюиії жанру пісні без слів - одного з найяскравіших репрезентантів романтичного стилю. Пісні без слів украӥнських композиторів (Й. Витвицького, Т. Шпаковського, М. Лисенка, Я. Степового С. Людкевича), написані на різних етапах романтичної епохи, розглядаються в еволючійному русі в контексті європейського романтизму. На підставі компаративного аналізу виявлено жанрово-стилістичні риси, щзо свідчать про типологічну спільність розвитку романтизму в різних національних культурах, про вплив творчості Ф. Мендельсона на украӥнський романтизм, та навпаки, виокремлено відмінні ознаки, які констатують оригінальність жанрових трактувань украӥнських митців. Визначено, щзо кульмінацією розвитку романтизму в еволюиіï ияього жанру стали пісні без слів М. Лисенка (ор. 10 № 1, 2), у яких композитор створив український національний жанровий різновид.

Ключові слова: стиль, жанр, романтизм, еволючія, українська фортепіанна музика, пісня без слів, начіональний різновид жанру.

В статье исследуется проблема стилевой динамики романтизма в украинской фортепианной музыке XIX-нач. XX вв. на примере эволюции жанра песни без слов - одного из ярчайших репрезентантов романтического стиля. Песни без слов украинских композиторов (И. Витвицкого, Т. Шпаковского, Н. Лысенко, Я. Степового С. Людкевича), написанные на разных этапах романтической эпохи, рассматриваются в эволючионном прочессе в контексте европейского романтизма. На основе компаративного анализа выявлены общие жанрово-стилистические черты, которые свидетельствуют о типологической общности развития романтизма в разных национальных культурах, о влиянии творчества Ф. Мендельсона на украинский романтизм, и наоборот, выделены отличительные качества, констатирующие оригинальность жанровых трактовок украинских композиторов. Определено, что кульминацией романтизма в эволючии этого жанра стали песни без слов Н. Лысенко (ор. 10 № 1, 2), в которых композитор создал украинский национальный жанровый инвариант.

Ключевые слова: стиль, жанр, романтизм, эволючия, украинская фортепианная музыка, песня без слов, наџиональный инвариант жанра. 
The article deals with the analysis of dynamics of Romanticism in Ukrainian piano music of $19^{\text {th }}$ century - the beginning of $20^{\text {th }}$ century by the example of evolution of the genre song without words - one of the most prominent representatives of the romantic style. Songs without words written by Ukrainian composers (I. Vytvytskyi, T. Shpakovskyi, M. Lysenko, I. Stepovyi, and S. Lyudkevych) in different periods of romantic epoch are considered in the evolutionary process in the context of European Romanticism. Based on the comparative analysis the genre-stylistic peculiarities are defined, which indicate the typological commonality of the development of Romanticism in different national cultures, the influence of F. Mendelsohn's creative work on the Ukrainian Romanticism, and vice versa: the distinctive features were defined, which express the uniqueness of the genre song without words interpretations by Ukrainian artists. It is defined that the culmination of Romanticism in evolution of this genre are songs without words written by M. Lysenko (op. 10 № 1, 2), in which the composer has created the Ukrainian national version of this genre.

Key words: style, genre, Romanticism, evolution, Ukrainian piano music, song without words, national version of genre.

Звернення до теми українського романтизму викликане необхідністю вивчення маловідомих сторінок історії вітчизняного мистецтва. Незважаючи на наявність низки праць, в яких розглядалися музичні твори XIX ст., епохи романтизму, стильова специфіка композиторської спадщини цього, чи не найважливішого в нашій культурі періоду, упродовж якого сформувалася й еволюціонувала національна музична класика, досі залишається малодослідженою. Однією з причин цього було тривале невизнання романтизму в радянський час, коли через упередженість та ідеологічну заангажованість наукової думки під сумнів ставився сам факт його існування, не кажучи вже про наявність широкої наукової проблематики, зокрема національно-стильових аспектів цього історико-культурного феномену.

Дослідження стильових процесів епохи Романтизму активізувалося лише в XXIст. Так, Л. Корній уперше розглянула еволюцію українського музичного романтизму на тлі історичних, соціальних і культурних процесів XIX ст. [9]; Л. Кияновська дослідила стильову еволюцію в музичній культурі Галичини XIX - XX стст. [7]. Питання романтизму в українській музичній культурі XIX ст. порушено і в колективній праці науковців ІМФЕ ім. М. Т. Рильського НАН України [6].

Погоджуючись із позицією сучасного музикознавства пізнавати художні явища в історико-культурному розвитку, вважаємо перспективним дослідження проблеми стильового поступу романтизму в українській фортепіанній музиці, в якій цей стиль проявився особливо виразно.

Стильовий поступ - складний багаторівневий процес, утворений різними складовими, на кожній із яких, за логікою організації частин і цілого, позначається стан стильового розвитку. Оскільки в ієрархічній системі музичних компонентів «каталізатором» стилю аксіоматично вважається жанр, відповідно, чітке уявлення про характер стильових змін дає картина еволюції жанрів. Враховуючи той історичний факт, що протягом XIX - поч. XX стст. в Україні (як і в інших європейських країнах) 
інтенсивно розвивалася фортепіанна музика, є підстави вважати, що еволюція фортепіанних жанрів послідовно відбиває стильовий поступ українського романтизму. Відповідно, означену проблему доцільно дослідити на прикладі еволюції жанрових домінант - тих жанрів, які переважали та активно розвивалися у фортепіанній творчості українських композиторів упродовж окресленого періоду.

Однією з таких жанрових домінант була пісня без слів, провідний фортепіанний жанр епохи романтизму. Започаткований Ф. Мендельсоном у 30 х роках XIX ст., цей жанр упродовж цілого століття розвивався в музиці різних національних культур, увібравши весь образно-емоційний спектр романтичної естетики. До жанру пісні без слів, зокрема, зверталися французькі романтики К. Сен-Санс, Г. Форе, Ш. Алкан, російські- І. Ласковський, А. Рубінштейн та П. Чайковський, фінські - Я. Сібеліус та Е. Мелартін, українські - Й. Витвицький, Т. Шпаковський, М. Лисенко, Д. Січинський, Я. Степовий, С. Людкевич.

Популярність пісні без слів була зумовлена передусім їі генетичним зв'язком iз первинним жанром фольклору - піснею, що була основним інтонаційним джерелом романтичної творчості. Крім того, сама концепція жанру та його модель, створені Ф. Мендельсоном, виявилися прийнятними музичною культурою завдяки таким романтичним особливостям як камерність форми (тип фортепіанної мініатюри), універсальність піаністичної техніки, розрахованої як на побутово-аматорське, так і професійне виконання, та багатство образного змісту. К. Зенкін, який досліджував пісні без слів Ф. Мендельсона в контексті розвитку фортепіанної мініатюри, класифікував їх за образно-змістовими та жанрово-інтонаційними ознаками на чотири контрастні групи: а) хорова пісня; б) сольна лірична пісня-романс; в) поемні (баладні та скерцозні) ускладнення пісенної основи; г) «жанрове скерцо» [4, с. 69]. Крім того, всередині цих умовно визначених груп простежується поєднання різножанрових витоків, визначених самим автором музики: німецької народної пісні, венеціанської гондольєри, мисливської пісні, колискової, траурного маршу.

Різноманітні втілення пісня без слів одержала в українській фортепіанній музиці епохи романтизму. Романс без слів «Тихий вечір над морем» Т. Шпаковського, Пісня без слів «Сльоза» Й. Витвицького, пісні без слів М. Лисенка (ор. 10 № 1, 2), Я. Степового (ор. 9 № 3) та С. Людкевича («Баркарола») становлять еволюційну шкалу, на якій позначилася специфіка розвитку стильових ознак українського музичного романтизму.

Пісням без слів українських композиторів епохи романтизму ще не присвячувалися спеціальні дослідження, але у вітчизняному музикознавстві $є$ праці й розвідки, які певним чином стосуються окремих творів цього жанру. Так, у дослідженні В. Клина пісні без слів Й. Витвицького, М. Лисенка, С. Людкевича та Я. Степового згадуються у загальному контексті фортепіанних творів українських композиторів XIX-XX стст. [8, с. 10-15]. Дві пісні без слів М. Лисенка (ор. 10) розглядалися Л. Корній з погляду специфіки романтичного стилю цього композитора [9, с. 444-446]. Авторка визначила в них ознаки загально-романтичної та питомо-національної української образності та стилістики. Національну самобутність згаданих п’єс М. Лисенка відзначали й І. Зінків та Б. Фільц [6, с. 416]. Обидва Лисенкові твори також привернули увагу Н. Рябухи, яка вивчала феномен жанру мініатюри на матеріалі фортепіанних творів українських композиторів кінця XIX - XX стст. [12, с. 102-105]. 
Керуючись постулатом М. Михайлова «еволюція жанрів є результатом стильової еволюції» [11, с. 102], у цій статті вперше ставиться мета виявити стильовий поступ українського музичного романтизму на прикладі еволюції жанру пісні без слів. Для цього пісні без слів згаданих українських композиторів розглядаються у відповідному жанровому контексті європейського музичного романтизму. Для розкриття проблеми еволюції цього жанру обрано історично-порівняльний метод дослідження, який полягає у виявленні спільних та відмінних ознак між піснями без слів, написаними українськими митцями, та піснями без слів романтиків інших національних культур, зокрема, $Ф$. Мендельсона, зачинателя цього жанру.

В основу дослідження жанрово-еволюційного процесу покладено концепцію історичного розвитку жанру М. Арановського, згідно з якою жанр як музичноісторичний об’ єкт «переживає» три етапи: формування, стабілізації та дестабілізації $[1$, с. 5]. Підводячи стильові узагальнення, автор статті спирається на положення Л. Корній щодо основних тенденцій в еволюції українського романтизму [9, с. 15]: засвоєння інонаціональних жанрово-стильових традицій (стильова адаптація) та формування нових стильових ознак (стильова генерація). Терміни «стильова адаптація» та «стильова генерація» уперше були використані С. Тишком [13, с. 6].

Беручи до уваги той об'єктивний факт, що в розвитку українського романтизму домінував процес адаптації, у процесі виявлення еволюційних змін невідворотно виникає проблема взаємодії традиції та новаторства. Спираючись на науковий досвід О. Зінькевич у вивченні цієї проблеми [5], у піснях без слів українських романтиків визначаємо такі рівні прояву інонаціонального творчого впливу: а) орієнтація на сталу жанрову модель; б) запозичення специфічних рис музичної мови або ж цілого жанровостилістичного комплексу. Використовуючи термін «жанрова модель», посилаємося на визначення А. Баєвої, згідно з яким «модель жанру» трактується як жанровий зразок, у якому наявні викристалізувані змістові, композиційні та стилістичні параметри [2, с. 128]. Такою жанровою моделлю для українських композиторів слугували пісні без слів Ф. Мендельсона.

Відомо, що пісні без слів Ф. Мендельсона почали друкуватися в Україні вже 3 кінця 30 х років XIX ст., тобто невдовзі після появи перших опусів цих п’єс. Зважаючи на характерні тенденції розвитку романтизму в українській музичній культурі першої половини XIX ст., можна припустити, що ці твори, подібно до інших жанрових зразків європейської романтичної фортепіанної мініатюри, не тільки швидко ввійшли в український музичний побут і концертне життя, а й асимілювався в аматорській та професійній творчості.

В архівах зберігаються два жанрових варіанти пісні без слів, які з'явились у cер. XIX ст.: романс без слів «Тихий вечір над морем», написаний Т. Шпаковським, та пісня без слів «Сльоза» Й. Витвицького (обидва твори згадуються в «Історії української музики» $[6$, с. 364,387$])$.

Ці твори мають програмні назви, що характерно для розвитку української фортепіанної творчості сер. XIX ст. Оскільки цих п'єс немає в нашому розпорядженні, відповідно, визначити їхні жанрово-стилістичні особливості не уявляється можливим. Проте ознайомлення з іншими творами Т. Шпаковського та Й. Витвицького (зокрема 3 
«Інтермеццо-мазуркою», «Українською рапсодією» Т. Шпаковського та «Коломийкою», «Шумкою» та «Другою українською шумкою» Й. Витвицького), так само, як і біографічні відомості про цих музикантів, певним чином проливають світло на загальний технічний і художній рівень їхньої творчості загалом, в тому числі й згаданих пісень без слів.

Отже, зважаючи на той факт, що Т. Шпаковський був блискучим піаністом, який виконував власні твори, можна припустити, що Романс без слів «Тихий вечір над морем» має концертний характер, подібно до інших згаданих п’єс цього митця. Вірогідно, у цьому творі, так само, як у Інтермецо-мазурці та Українській рапсодії, виразно простежується наслідування жанровим, образно-композиційним і стилістичним традиціям Ф. Мендельсона, в якого Т. Шпаковський навчався у Лейпцигу. Водночас жанрове визначення п’єси романс без слів, як і у випадку з назвою його рапсодії («українська»), підкреслює тяжіння композитора до українських національних жанровоінтонаційних джерел. Імовірно, образність, фактура та стилістика цього твору певним чином апелюють до жанру романсу.

На відміну від Т. Шпаковського, Й. Витвицький був аматором, який писав музику переважно для домашнього репертуару. Його твори загалом позначені камерністю і простотою форми, невибагливістю фактури і стилістики. Припускаємо, що не є винятком і пісня без слів «Сльоза», в основі якої - «українська народнопісенна мелодія у вигляді звичайного аранжування» [6, с. 363-364].

Підсумовуючи сказане, формування жанру пісні без слів в українській фортепіанній музиці романтизму відбувалося в середині XIX ст. у творчості Т. Шпаковського та Й. Витвицького. Жанрові трактування цих композиторів, імовірно, були різними, зважаючи на істотну відмінність стильової манери кожного з митців. У творі Т. Шпаковського, вірогідно, переважають універсально-романтичні ознаки художнього письма (зокрема, лейпцизької музичної традиції середини XIX ст.), а в пісні без слів Й. Витвицького українські народно-жанрові риси. При всій уявній відмінності, обидва твори об’єднані програмністю ліричного змісту, характерною для української музичної культури того часу: пейзажного (Т. Шпаковський) та сентиментального (Й. Витвицький).

Наступний етап еволюції пісні без слів в українській музиці романтизму пов'язаний iз творчістю М. Лисенка. Дві його пісні без слів (ор. 10), написані в середині 70-х років XIX ст., демонструють різні грані одного лірико-психологічного образу з яскраво вираженим українським національним забарвленням. При цьому обидві пісні без слів написані в традиціях фортепіанної мініатюри зрілого романтизму, ввібравши характерні ознаки жанрової моделі пісні без слів Ф. Мендельсона. Ці твори мають тричастинну форму з динамічною репризою, що притаманна більшості фортепіанних п'єс європейських композиторів-романтиків, кантиленну мелодику (вокального та інструментального характеру), вирізняються колористичною гармонією та багатством фактурних прийомів. Від жанрової моделі Ф. Мендельсона обидві п'єси успадкували простоту і невимушеність пісенної мелодії, універсальність фортепіанної техніки (яка хоч і не передбачала концертного виконання, але все ж вимагала від виконавця досить майстерного володіння інструментом), а також різноманітні принципи тематичного розвитку та стилістичні ознаки. 
У Першій пісні без слів (ор. 10 № 1) особливо виразно проявилася стихія української народної пісні. Її вплив простежується на різних рівнях твору: у специфіці структури, драматургії, мелодики, гармонії та фактури. Особливістю драматургії п’єси є варіантний принцип тематичного розвитку, внаслідок якого відбувається оновлення тематизму, його перехід у нову якість, і врешті - динамізація образу в репризі. Такий тип розвитку тематизму характеризує більшість пісень без слів Ф. Мендельсона. Імовірно, М. Лисенко, добре знаючи ці твори, орієнтувався на загальні ознаки жанрової моделі німецького романтика. Принаймні відомо, що під час навчання у Лейпцизькій консерваторії, він вивчав і грав твори Ф. Мендельсона. Про це, зокрема, пише Л. Гнатюк [3].

Водночас варіантне розгортання тематизму, що вирізняє драматургію цієї пісні без слів, властиве й українському народнопісенному стилю, який М. Лисенко успадкував на генетичному рівні. Особливості стилістики й фактури також свідчать про свідому орієнтацію композитора на український фольклор. Так, основна тема за своєю структурою, інтонаційністю, ладовою специфікою і гармонічним складом є доволі близькою до української ліричної протяжної народної пісні. На це вказують такіії ознаки: строфічність будови $(\mathrm{a}+\mathrm{b}+\mathrm{b} 1)$, неквапливий розмірений темп і характер розгортання мелодичної лінії, оздобленої щемливими затриманнями і форшлагами, широта дихання з поступовим збільшенням діапазону мелодії, рівновага ритмічних формул, забарвлення паралельним мажором з його медіантою в рамках панівного гармонічного мінору (e-moll), використання переінтонування і перегармонізації як засобів розвитку. Основна тема цього твору є зразком «фортепіанної кантилени з українською національною специфікою» [9, с. 443], цілком відповідаючи характеристиці української народнопісенної лірики, яку дав сам композитор: «у мелодії українській - здебільшого (коли можна так висловитися) сугубо мінорній, з мелізмами, що нагадують не фантастичність прикрас, а переважно надірваний зойк, з дрібними інтервалами й характерними, несподівано сміливими підвищеннями, з рисунком симетричним i правильним, ритмом здебільшого постійним - відбився, як у дзеркалі, тип українця, миролюбного й глибокого характером, палкого й пристрасного з природи, з естетичним почуттям і з розумом споглядальним» [10, с. 31$]$.

Фольклорної якості надає цій музиці й специфіка фактури, що нагадує партитуру українського народно-хорового багатоголосся. Тема твору починається одноголосно, наче зачин хорової пісні, але дедалі «обростає» підголосками, які формують лінії нових самостійних голосів. Особливу увагу М. Лисенко приділяє нижнім голосам: увиразнює їх поступовим мелодичним рухом (як діатонічним, так і хроматичним) та активною ритмікою. У цій поліфонічно насиченій фактурі все ж виділяється чотириголосний склад, у якому помітно дотримання композитором академічних правил голосоведіння.

Орієнтація М. Лисенка на народну пісню в іiі хоровому звучанні була своєрідним продовженням традиції жанру Ф. Мендельсона, який створив цілу групу пісень без слів саме в характері народно-хорової пісні (ор. 19 № 3, 4, ор. 38 № 4, ор. 53 № 5, ор. 62 № 4, op. 102 № 6). Однак жанрові трактування цих композиторів виявилися різними, зважаючи на істотну відмінність національних традицій українського й німецького народного хорового співу. Якщо лейпцизький романтик передав хорове звучання через 
гомофонно-гармонічний склад мислення, характерний для німецького народного багатоголосся, то М. Лисенко спирався на ті поліфонічні засоби, які зумовлені природою українського народно-хорового співу.

Українське національне мислення М. Лисенка самобутньо проявилося й у Другій пісні без слів (ор. 10 № 2). На відміну від першої п’єси цього опусу, в якій сконцентровано суто ліричну якість української народної пісні, цей твір має різножанрові народнопісенні витоки: пісню-романс та лірико-побутову пісню. Жанровоінтонаційне багатство тематизму зумовило, відповідно, більш складну драматургію, побудовану на вільному розвиткові контрастного тематичного матеріалу. У цьому сенсі український композитор продовжив традицію Ф. Мендельсона, в піснях без слів якого панівна тема часто сусідує з епізодами, контрастними за образністю, інтонаційністю та фактурою (зокрема, це пісні без слів: ор. 19 № 4, ор. 30 № 9, ор. 38 № 16, ор. 53 № 23).

У структурному плані Друга пісня без слів має традиційну для зрілої романтичної мініатюри тричастинну форму з контрастною серединою, динамічною репризою та кодою. 3 погляду інтонаційної специфіки, основна тема, що розвивається у крайніх розділах твору, синтезує жанрові ознаки пісні-романсу та української народної пісні. Романсова природа тематизму проявляється у поступовому русі мелодії з широким диханням, врівноваженою ритмікою і чітким фразуванням, підкресленим кадансами. Разом з тим, унісонне звучання кадансу вказує на зв'язок із традицією українського народного багатоголосся. Народне забарвлення цієї теми особливо відчутне в кадансі другого періоду, оздобленого характерними для хорового співу підголосками.

Колорит української народної пісні проявився і в тематизмі середнього розділу, який композитор теж наділив ознаками українського народно-хорового співу. Ця частина, хоч і побудована на розвиткові одного з тематичних елементів основної теми, але має контрастне звучання по відношенню до крайніх розділів. Контраст утворюється, передусім, за рахунок зміни тональності й фактурного викладу. Виразного народного звучання їй надають ладова мінливість, модалізми, які утворюються в процесі перегармонізації мелодії, активний підголосковий рух.

Жанрово-стилістичний аналіз двох пісень без слів (ор. 10) М. Лисенка виявив, що український композитор значно збагатив цей романтичний жанр українською національною характеристичністю, спираючись, при цьому, на загальні образні, композиційні та стилістичні ознаки жанрової моделі Ф. Мендельсона. 3 погляду жанрово-еволюційного процесу це дає підстави виокремити обидві п'єси як етап стабілізації жанру та його модифікації у напрямку набуття української національної якості звучання. Найбільш органічно ознаки жанрової модифікації проявилися у Першій пісні без слів, у якій Лисенкові вдалося створити український національний різновид цього жанру.

Останній етап еволюції жанру пісні без слів (1910-і роки) представлений творчістю Я. Степового (Пісня без слів ор. 9 № 3) та С. Людкевича (Пісня без слів «Баркароля»). Ці твори вирізняє емоційно-напружений тонус, породжений психологізацією художнього змісту. При цьому, вираженням суб'єктивного начала тут виступає не так романтична почуттєвість, як рафінований інтелектуалізм та психологічна загостреність, притаманні естетиці епохи «Fin de siecle». Ï̈ характерні ознаки - примат підсвідомого, 
химерного, зумовлений почуттям розгубленості героя перед «сутінками цивілізації» [14] на початку XX ст., його схильність до споглядання і рефлексії якраз і визначили образно-емоційну якість пісень без слів Я. Степового та С. Людкевича. Невипадково в обох п’єсах панує похмурий присмерковий настрій, підкреслений мінорною тональністю та низьким регістром фортепіано. У Пісні без слів Я. Степового затьмарений колорит передає стан глибокої задумливості, цілісність якого час від часу порушується тимчасовими спалахами химерних спогадів-видінь. У Пісні ж без слів С. Людкевича, в якій домінує безперервний бурхливий рух, темні барви, навпаки, надають звучанню драматичного характеру.

Оновлення образно-емоційної сфери жанру спричинило пошук відповідних засобів драматургії і стилістики. Зокрема, визначальною драматургічною особливістю обох творів стало подолання інерції традиційного пісенного розгортання. Особливо це помітно в Пісні без слів Я. Степового, в якій автор уникає характерного для кантилени плавного мелодичного руху. Інтонаційний малюнок основної теми нагадує ламану лінію, утворену різноспрямованими терцієвими, квартовими, тритоновими й септимовими ходами:

III - VII\# - V - VII\# - V - I - III - V - IV\# - V - III - I - IV\# - V - III - V - VII\# - V.

Рвучкості мелодичної лінії сприяє і ритмічна нестабільність, виражена чергуванням синкопованих сегментів із фразами, утвореними рівним рухом шістнадцятих на розвиткових ділянках твору. Усе це, а також, тональна нестійкість, підсилена частими еліптичними зворотами та контрастними зіставленнями далеких тональностей, «скерцозні» інтонації пасажів середньої частини твору вказують на інструментальний спосіб розгортання тематичного матеріалу.

Відхід від традиційної пісенності жанру спостерігається і в Пісні без слів C. Людкевича, незважаючи на жанрове уточнення автора «Баркарола», яке апелює, власне, до пісенних витоків. Італійська назва вказує також на прямий зв' язок цього твору 3 жанровою традицією Ф. Мендельсона, серед пісень без слів якого - три пісні венеціанського гондольєра. Подібно до Ф. Мендельсона, український композитор поєднав у своєму творі ознаки сольної ліричної пісні-романсу та клавірної прелюдії. Так само, як у Ф. Мендельсона «прелюдійність» має тут «бахівські» риси: фігураційний рух та імпровізаційний характер драматургічного розвитку. Спільним для обох композиторів є також вибір двочастинної форми, характерної як для жанру побутової пісні, так і для ранньокласичних клавірних творів, зокрема, прелюдій Й. С. Баха, на які орієнтувався у своїй творчості Ф. Мендельсон.

Та якщо пісні венеціанського гондольєра тісніше пов'язані з побутовою піснею (зважаючи хоча би на певну автономність ліній мелодії і гармонічного супроводу), то прелюдійність «Баркароли» С. Людкевича має інструментально-поліфонічний характер і спосіб вислову. Порівняно із п’єсами Ф. Мендельсона фігураційний рух фактурного викладу тут значно інтенсивніший, його інтонаційні формули з «остинатним» басом та обіграванням зменшених гармоній, наближаються до характерних фігураційних прийомів прелюдій Й. С. Баха, зокрема, Прелюдії c-moll із циклу 24 прелюдій і фуг (І том Добре Темперованого Клавіру). Так само, як і в Й. С. Баха, мелодика «Баркароли», в цілому, є доволі статичною. Розташована у верхньому голосі акордово-поліфонічної 
фактури, вона суцільно підпорядкована гармонічному розвитку. Лише в кульмінаційній зоні композитор надає їй більшої активності і пластики, виразніше виділяючи щемливі інтонації предйомів і затримань, характерних для італійської народної пісні. Загалом же, мінорна тональність мелодії, iї низхідний рух на фоні бурхливих фактурних фігурацій підсилюють драматичний характер твору.

Таким чином, у піснях без слів Я. Степового та С. Людкевича спостерігається дестабілізація жанрової моделі ХІХ ст., зумовлена зміною естетико-художніх орієнтирів в епоху «Fin de siecle». Трансформація образно-емоційної сфери жанру в обох випадках привела до руйнації характерної ознаки жанру пісні без слів - ліричної мелодійності, внаслідок чого жанр утратив генетичний зв'язок із пісенними витоками.

Отже, в еволюції жанру пісні без слів в українській фортепіанній музиці романтизму простежуються три етапи. На першому етапі (40-60 p. p. XIX ст.) відбувалося формування жанрових ознак у творчості Т. Шпаковського таЙ. Витвицького. Ці п'єси становили різні шляхи розвитку жанру: універсально-романтичний (Т. Шпаковський) та національний з опорою на українські народно-жанрові джерела (Й. Витвицький). У стильовому відношенні у творах обох композиторів домінували адаптаційні процеси, зумовлені опануванням жанрової стилістики фортепіанної мініатюри європейського романтизму і, зокрема, пісень без слів Ф. Мендельсона.

Другий етап, позначений стабілізацією і модифікацією жанру, пов'язаний із творчістю М. Лисенка. Дві його пісні без слів (ор. 10), написані в 70-х роках XIX ст. свідчать про досконале оволодіння формою і стилістикою жанрової моделі європейської романтичної мініатюри. Крім того, у цих творах яскраво проявилася характерна тенденція зрілого романтизму - створення національної якості жанру. Обидві п’єси М. Лисенко наділив українською національною характеристичністю, спираючись на образність та інтонаційність народної пісні. Найбільш органічно жанрова модифікація проявилася у Першій пісні без слів цього опусу, в якій композитору вдалося створити український національний різновид цього жанру. Виходячи з цього, для другого етапу було характерно як засвоєння стильових ознак, так і стильова генерація.

На останньому етапі (1910-ті роки) простежується дестабілізація жанру. Пісні без слів Я. Степового та С. Людкевича демонструють відхід від романтичної жанрової моделі XIX ст., увібравши розмаїті ознаки мистецтва епохи «Fin de siecle». Інтелектуалізація і психологічна загостреність образного змісту цих творів сприяли пригніченню якості ліричної кантиленності, яка генетично властива пісенному жанру. Таким чином, у піснях без слів Я. Степового та С. Людкевича цей жанр значно віддалився від своїх витоків. У стильовому відношенні в обох творах спостерігається органічне взаємопроникнення універсально-романтичних і українських національних ознак художнього письма, що вказує на злиття тенденцій стильової адаптації та генерації індивідуальних національно-виразних стилів.

Пропонованою статтею відкриваються нові наукові обрії у вивченні романтизму, зокрема його національного дискурсу. Виявлені ознаки стильового поступу романтизму в українській фортепіанній музиці на прикладі еволюції жанру пісні без слів мають загальний характер і можуть бути використані у вивченні стильових аспектів українського музичного романтизму на прикладі інших жанрів. 


\section{Лimepamypa:}

1. Арановский М. Г. Симфонические искания: проблема жанра симфонии в советской музыке 1960 - 1975 г2. : исследовательские очерки / М. Г. Арановский. - Ленинград : Сов. композитор, 1979. - 287 с. 2. Баева А. Принципь моделирования жанра и музыкальной драматургии в опере Стравинского «Похождения повесы» / А. Баева // Музыкальныий современник : сб. ст. - Вып. 6. - Москва : Сов. композитор, 987. - С. 127-147. 3. ГнатюкЛ. А. Микола Лисенко і Лейпиизька консерваторія: німечька музично-теоретична школа як фундамент європейської музичної освіти : дис. ... канд. мистецтвознавства : спеи. 17.00.02Музичне мистецтво / Гнатюк Лариса Анастасіївна ; Київська держ. консерваторія ім. П. І. Чайковського. - Київ, 1994. - 206 с. 4. Зенкин К. В. Фортепианная миниатюра и пути развития музыкального романтизма / К. В. Зенкин. - Москва, 1997. - 415 с. 5. Зинькевич Е. С. Методологические аспекты проблемы традиции и новаторства / Е. Зинькевич // Исторические аспекты теоретических проблем в музыкознании : сб. науч. труд. Киевская гос. консерватория им. П. И. Чайковского. - Киев, 1985. - С. 65-80. 6. Історія украӥнської музики: У 6 m., Т. 2: ХІХ ст. [голова ред. Колегї Г. А.Скрипник]. -/НАН України, ІМФЕ ім. М. Т. Рильського; - Київ : ІМФЕ ім. М. Т. Рильського НАН України, 2009. - 800 с. 7. Кияновська Л. О. Стильова еволючія галицької музичної культури XIX-XX ст. : монографія /Любов Кияновська. - Тернопіль : Астон, 2000. - 339 с. 8. Клин В. Л. Українська радянська фортепіанна музика (1917-1977) / В. Л. Клин. - Київ : Наукова думка, 1980. -313 с. 9. Корній Л. П. Історія української музики. Ч. III. - ХІХ ст. / Л. П. Корній. - Київ ; НьюЙорк : Вид. М. П. Кочъ, 2001. - 478 с. 10. Лисенко М. В. Характерні музичні особливості українських дум і пісень, виконуваних кобзарем Вересаєм [ Ред., передмова та примітки М. Гордійчука]. -/ М. В. Лисенко. - Київ : Мистеитво, 1955. - 88 с. 11. Михайлов М. К. Стиль в музыке: исследование / М. К. Михайлов.- Ленинград: Музыка, 1981. - 264 с. 12. Рябуха Н. О. Мініатюра як феномен музичної культури (на матеріалі фортепіанних творів украйнських композиторів кіния XIX-XX cm.) : автореф. дис. на здобуття наук. ступеня канд. мистецтвознавства : спец. 17.00.03 - Музичне мистецтво / Н. О. Рябуха ; Харк. держ. акад. культури. -Харків, 2004. - 20 с. 13. Тышко С. В. Проблема национального стиля в русской опере. Глинка. Мусоргский. Римский-Корсаков / С. В. Тышко-Киев : Киевская государственная консерватория имени П. Чайковского, 1993. - 117 с. 14. Шпенглер О. Закат Европь:: очерки морфологии мировой истории. Т. 1. Образ и действительность / О. Шиенглер ; [пер. с нем. Н. Ф. Гарелин; Авт. комментариев Ю. П. Бубенков и А. П. Дубнов; Худ. обл. М. В. Драко]. - Минск : Попурри, 1998. - 688 с. 